\title{
Lateral flow sand filters are effective for removal of antibiotic resistance genes from domestic wastewater
}

Hayward , Jennifer ; Huang, Yannan; Yost, Christopher; Hansen, Lisbeth Truelstrup; Lake, Craig; Tong, Anthony; Jamieson, Rob C.

Published in:

Water Research

Link to article, DOI:

10.1016/j.watres.2019.07.004

Publication date:

2019

Document Version

Peer reviewed version

Link back to DTU Orbit

Citation (APA):

Hayward, J., Huang, Y., Yost, C., Hansen, L. T., Lake, C., Tong, A., \& Jamieson, R. C. (2019). Lateral flow sand filters are effective for removal of antibiotic resistance genes from domestic wastewater. Water Research, 162, 482-491. https://doi.org/10.1016/j.watres.2019.07.004

\section{General rights}

Copyright and moral rights for the publications made accessible in the public portal are retained by the authors and/or other copyright owners and it is a condition of accessing publications that users recognise and abide by the legal requirements associated with these rights.

- Users may download and print one copy of any publication from the public portal for the purpose of private study or research.

- You may not further distribute the material or use it for any profit-making activity or commercial gain

- You may freely distribute the URL identifying the publication in the public portal 
1 Lateral Flow Sand Filters are Effective for Removal of Antibiotic Resistance Genes from

2 Domestic Wastewater

3 Jennifer L. Hayward ${ }^{\mathrm{a}}$, Yannan Huang ${ }^{\mathrm{a}}$, Christopher K. Yost ${ }^{\mathrm{b}}$, Lisbeth Truelstrup Hansen ${ }^{\mathrm{c}}$, Craig

4 Lake $^{\mathrm{a}}$, Anthony Tong ${ }^{\mathrm{d}}$, Rob C. Jamieson ${ }^{\mathrm{a}}$

$5 \quad{ }^{a}$ Centre for Water Resources Studies, Department of Civil \& Resource Engineering,

6 Dalhousie University, 1360 Barrington Street, Halifax, Nova Scotia, Canada, B3H 4R2

$7 \quad{ }^{b}$ Department of Biology, University of Regina, 3737 Wascana Parkway, Regina, Saskatchewan,

8 Canada, S4S 0A2

9 'National Food Institute, Technical University of Denmark, DK-2800 Kongens Lyngby, 10 Denmark.

$11{ }^{\mathrm{d}}$ Department of Chemistry, Acadia University, 6 University Avenue, Wolfville, Nova Scotia,

12 Canada, B4P 2R6

13 (jenny.hayward@dal.ca; y.huang@dal.ca, chris.yost@uregina.ca; litr@food.dtu.dk;

14 craig.lake@dal.ca; anthony.tong@acadiau.ca; jamiesrc@dal.ca)

15 *Corresponding author: Rob Jamieson, Dalhousie University, jamiesrc@dal.ca

16 Keywords: antibiotic resistance genes (ARGs), on-site wastewater treatment systems (OWTS),

17 wastewater treatment, qPCR, antibiotic resistant bacteria (ARB), antimicrobial resistance (AMR)

18

19 Abstract 
20 The ability of lateral flow sand filters, used as on-site wastewater treatment systems (OWTS), to

21 remove antibiotic resistance genes (ARGs), antibiotic resistant bacteria (ARB), and other

22 relevant genetic markers (HF183, 16S rRNA, and int1) was assessed. Municipal wastewater was

23 settled in a septic tank prior to loading into six pilot-scale lateral flow sand filters comprised of

24 three different sand media types, at 5 and 30\% slopes. The sand filters were sampled bi-weekly

25 for: 9 ARGs and 3 other complimentary gene markers (sul1, sul2, qnrS, tetO, ermB, bla $a_{\text {TEM }}$,

26 bla $a_{C T X-M}$, mecA, vanA, int1, HF183, 16S rRNA), and conventional microbial and water quality

27 indicators, from July to November in 2017, and four times in the summer of 2018. The sand

28 filters were observed to attenuate 7 of the ARGs to mostly below $2 \log$ gene copies per mL. Log

29 reductions ranging from 2.9 to 5.4 log were observed for the removal of absolute abundances of

30 ARGs from septic tank effluent in 5 of the 6 sand filters. The fine-grained filter on the $5 \%$ slope

31 did not perform as well for ARG attenuation due to hydraulic failure. The apportionment of cell-

32 associated versus cell-free DNA was determined for the gene markers and this indicated that the

33 genes were primarily carried intracellularly. Average log reductions of ARB with resistance to

34 either sulfamethoxazole, erythromycin, or tetracycline were approximately 2.3 log CFU per mL

35 within the filters compared to the septic tank effluent. This field study provides in-depth insights

36 into the attenuation of ARB, ARGs, and their genetic compartmentalization in variably saturated

37 sand OWTS. Overall, this type of OWTS was found to pose little risk of antimicrobial resistance

38 contamination spread into surrounding environments when proper hydraulic function was

39 maintained.

40 1. Introduction

41 Antibiotic resistance has become a leading threat to global public health as treatable pathogenic

42 microbial infections have acquired resistance to conventional antibiotics (WHO, 2014). 
43 Anthropogenic practices, including the use of clinical and agricultural antibiotics and

44 antimicrobial product usage, can encourage the proliferation of antimicrobial resistance (AMR)

45 by introduction of selective pressure on bacteria (Davies and Davies, 2010; Kolář et al., 2001). A

46 hot spot for AMR development is in municipal wastewater treatment plants (WWTPs), where

47 trace amounts of antibiotics taken within the general population are only partially metabolized,

48 which leads to the development of AMR in bacterial communities within wastewater process

49 streams (Munir et al., 2011). Antibiotic resistance in bacteria results from the expression of

50 antibiotic resistance genes (ARGs), acquired as mobile genetic elements (MGEs) via horizontal

51 gene transfer or as mutations via vertical transmission (Depardieu et al., 2007). Quantification of

52 abundances of antibiotic resistant bacteria (ARB), ARGs and MGEs in WWTPs and receiving

53 surface water environments have been conducted (Rizzo et al., 2013). ARG concentrations are

54 typically reduced within many WWTPs; however, they persist in surface water systems

55 downstream of effluent discharges (Freeman et al., 2018; McConnell et al., 2018a).

56 Understanding the environmental dimension of AMR is important to enable the prediction of the

57 spread of ARGs and AMR pathogens downstream of hot spots (Berendonk et al., 2015).

58 Removal, or conversely breakthrough, of ARGs and ARB within passive on-site wastewater

59 treatment systems (OWTS) and variably saturated subsurface environments is less extensively

60 studied. Despite this, antimicrobial products which encourage proliferation of AMR have been

61 observed in septic tank effluent from OWTS (Conn et al., 2010). Unproperly treated wastewater

62 in OWTS could pose a risk of bacterial contamination of surrounding drinking water resources

63 (Crane and Moore, 1984). Approximately 15\% and 20\% of the population uses OWTS for

64 provision of wastewater treatment in Canada and the United States, respectively. (Statistics

65 Canada, 2015; EPA, 2018). OWTS are the second most frequent source of fecal contamination 
66 of groundwater in the United States (Carroll et al., 2005). These can be a source of

67 contamination for groundwater and adjacent surface water systems if they are not properly

68 maintained. They may not be effective for attenuation of some types of contaminants of

69 emerging concern such as pharmaceuticals and personal care products (Schaider et al., 2017).

70 OWTS is often recommended to improve sanitation in developing nations due to relatively low

71 cost, low maintenance requirements, and technical feasibility (WWAP, 2017). Contamination of

72 groundwater with vectors of AMR from OWTS may be considered an issue of increased concern

73 due to elevated reported susceptibility of developing regions to AMR (Ashbolt et al., 2013).

74 While AMR prevalence in conventional centralized WWTPs is becoming increasingly better

75 characterized; there remains a knowledge gap in the efficacy of low-tech treatment options to

76 reduce risk of AMR contamination for developing countries (Bürgmann et al., 2018).

77 Treatment of ARGs with subsurface flow filter media has been studied by Anderson et al.

78 (2015). The authors observed that ARGs and ARB associated with sulfonamide and tetracycline

79 resistance adsorbed and persisted on the filter media, posing challenges for media disposal at the

80 end of the filter life cycle (Anderson et al., 2015). Rural OWTS and municipal WWTPs were

81 compared in China for ARG removal by Chen and Zhang (2013). The authors observed 1 to 3

82 log removal for ARGs in centralized WWTPs, but less effective removal for ARGs in rural

83 OWTS; potentially due to lower overall abundances of ARGs in OWTS (Chen and Zhang,

84 2013). The removal performance of ARGs in a horizontal subsurface flow constructed wetland

85 was studied by Nõlvak et al. (2013). ARG removal rates were higher in the wetland than

86 observed in conventional WWTPs. ARG carrying microorganisms interacted with the wetland

87 biofilm media; however, the exact attenuation mechanisms were not identified (Nõlvak et al., 88 2013). 
89 The ARGs which encode for AMR may be present intracellularly, as cell-associated ARGs, or 90 extracellularly, as cell-free ARGs. Biologically active DNA may be transmitted, as it can be

91 transported in saturated soil environments with limited degradation, due to advective transport 92 and reduced efficacies of inhibitory DNA nucleases (Poté et al., 2003). Cell-free DNA 93 (extracellular DNA) can persist in soil environments for periods of up to several years 94 (Pietramellara et al., 2009). Characterization of cell-associated versus cell-free ARGs was 95 recently identified by Zhang et al. (2018) within a WWTP in China. Cell-associated ARGs were 96 observed to decrease and an cell-free ARGs increased as effluent progressed through the 97 treatment train suggesting that the cell-free ARGs may persist and spread potential AMR 98 contaminants in receiving environments. This is only a public health threat if the environmental 99 DNA is taken up and becomes integrated into the genome of viable bacterial hosts that are 100 pathogenic.

101 This study was undertaken to characterize the risk posed by OWTS in terms of introducing 102 contaminants of AMR into water resources. The objectives were to assess attenuation of ARGs 103 and ARB in lateral flow sand filters, which are an alternative to conventional septic fields, but 104 exemplify similar physical filtration and biological treatment mechanisms. Sub-objectives for 105 this study included an assessment of whether sand filter design factors (grain size and filter 106 slope) affect treatment performance. The apportionment of cell-associated versus cell-free ARGs 107 was quantified to assess whether the cell-free ARGs can penetrate through the filter more easily 108 than cell-associated ARGs. This study provides a comprehensive assessment of an array of 109 design configurations of OWTS for attenuation of AMR contamination, with a range of ARGs, 110 other complimentary gene markers, ARB, and assessment of the genetic compartmentalization of 111 ARGs. 


\subsection{Sand filters description}

114 The experimental facility used in this study was located at the Bio-Environmental Engineering

115 Centre (BEEC) in Truro, Nova Scotia, Canada. Six lateral flow sand filters (SFs) were installed

116 at BEEC in 2004 and were constructed as per the Nova Scotia Environment On-Site Sewage

117 Disposal Technical Guidelines (Nova Scotia Environment, 2013; Sinclair et al., 2013). The

118 BEEC withdraws municipal wastewater from the Village of Bible Hill sewage collection line, 119 which is then pumped into a septic tank multiple times daily. A pump is programmed to 120 periodically dose the sand filters with septic tank effluent on a sub-daily basis via a flow splitter 121 box and gravel distribution trench. The flow of effluent within the filters has been characterized 122 as primarily tension saturated flow (Sinclair et al., 2013). Three different sand types were used in 123 the construction of the filters, consisting of fine, medium, and coarse-grained sand; with 124 saturated hydraulic conductivities of approximately $2.7 \times 10^{3}$ (SF1 and SF4), $6.3 \times 10^{3}$ (SF2 and 125 SF5), and $1.2 \times 10^{4} \mathrm{~cm} / \mathrm{d}$ (SF3 and SF6), respectively. Two slopes were assessed at 5 and 30\%; 126 design guidelines specify slopes ranging from 3 to 30\% (Nova Scotia Environment, 2013). The 127 grain size distributions are presented in the Supplemental Information (Figures S1 - S3). Each 128 sand filter including the gravel distribution trench was fully lined on the sides and bottom with a 129 high density polyethylene (HDPE) liner. The tops of the SFs were covered with filter fabric 130 overlain by approximately $0.6 \mathrm{~m}$ of topsoil. The SFs were constructed at a 1:10 scale as per the 131 dimensions illustrated in Figure 1. The effluent from each of the SFs was collected in a heated 132 sampling building where each filter had a separate calibrated tipping bucket gauge for flow 133 measurement. The influent was dosing rate was set by a programmable logic controller (PLC) to 134 emulate a domestic household use with peaks in flow at 8 am and $7 \mathrm{pm}$ (Figure S7 in the 
135 Supplemental Information). The number of bucket tips were logged on a 30-minute frequency

136 with a Campbell Scientific CR510 data logger (CSI, Logan, Utah, United States).

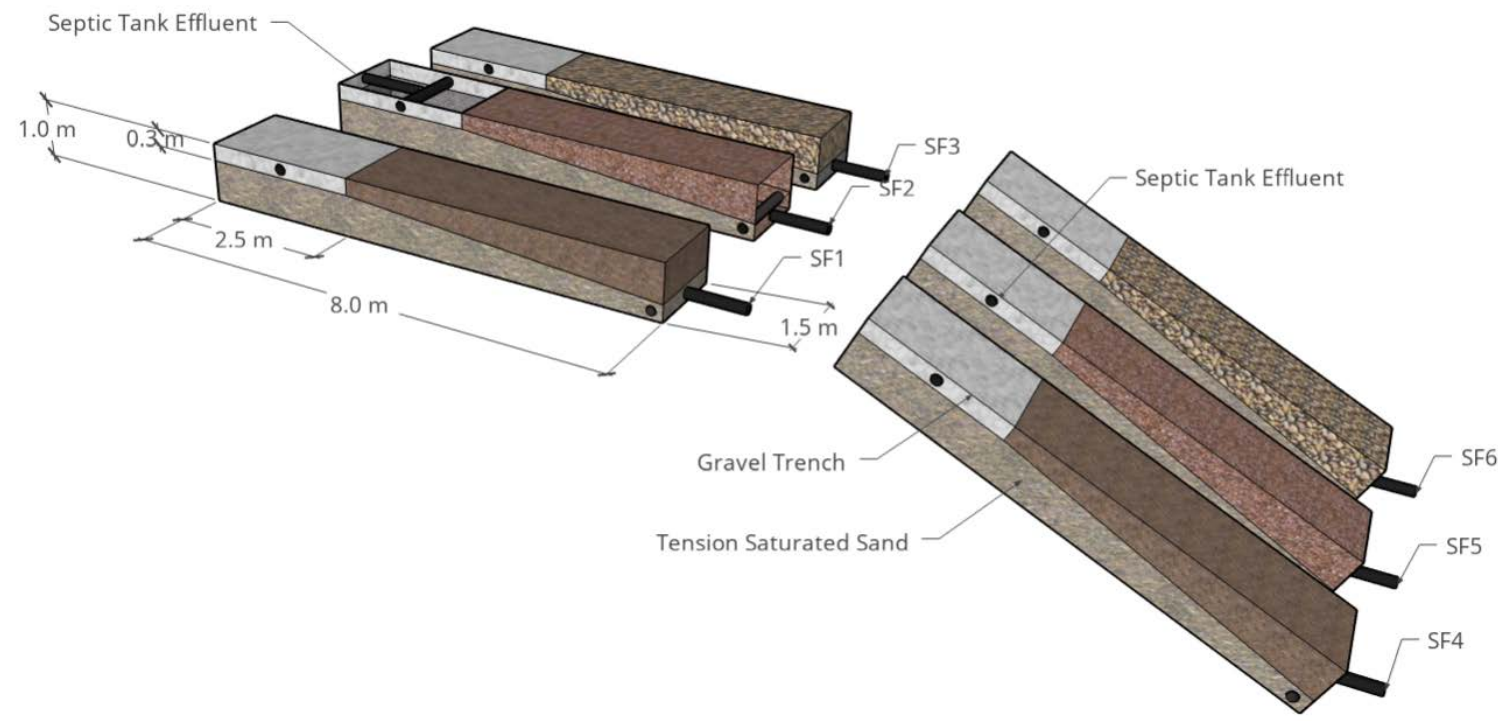

138 Figure 1. Schematic of the sand filter experimental layout (not to scale). Sand filter (SF)1 and 139 SF4 filter media consist of fine-grained sand, SF2 and SF5 are medium grained sand, and SF3 140 and SF6 are coarse grained sand. SF1 - SF3 are on a 5\% slope and SF4 - SF6 are on a 30\% 141 slope.

142 Average air temperatures near Truro were $18^{\circ} \mathrm{C}$ in July 2017 and ranged from a minimum of 12 143 to a maximum of $25^{\circ} \mathrm{C}$; during November averaged $3^{\circ} \mathrm{C}$, and ranged from -2 to $9^{\circ} \mathrm{C}$. During July 1442018 , air temperatures near Truro averaged 21, and ranged from 14 to $27^{\circ} \mathrm{C}$ (Government of 145 Canada, 2018).

\subsection{Water sampling}

147 All water samples were analyzed within 24 hours, except for antibiotics, which were analyzed 148 within a one week holding time. Water samples for metals analysis were acidified with nitric 149 acid to below pH 2 and store chilled for up to six months prior to analysis. 


\subsubsection{Conventional analysis}

151 Water samples were collected from: the raw wastewater directly off the Bible Hill line as it

152 discharged to a catch basin (1), the dosing box receiving effluent from the septic tank (1), and the

153 filter effluent from each of the six (6) SFs. The hydraulic retention time (HRT) of the dosing box

154 is approximately one day and the HRT of the septic tank is a minimum of two days. A total of

155 eight (8) sample events were conducted on approximately a bi-weekly basis from July 5 to

156 November 6, 2017, and analyzed for conventional wastewater parameters, as well as a suite of

157 ARGs and associated AMR genetic markers. Four (4) additional sets of samples were collected

158 during a two-day intensive sampling event that was conducted during a dry weather period on

159 July 16 and July 23, 2018 to assess for daily-scale temporal variability. The ARG results were

160 pooled for each day of this intensive sampling event for individual sample locations resulting in

161 two (2) additional samples sets for a total of ten sample points (10). The intensive sample results

162 were pooled due to low observed daily variability in concentrations as demonstrated in the

163 results of the intensive sampling that are summarized in Table S3 of the Supplemental

164 Information. During these two intensive sample event days additional microbial parameters

165 including antibiotic resistant bacteria (ARB), and cell-associated and cell-free DNA were

166 characterized. However, the ARB data collected during the intensive sampling event were not

167 pooled.

168 Water samples were collected in sterilized 1L plastic sample bottles and transported in coolers on

169 ice to the analytical laboratory at Dalhousie University in Halifax, Nova Scotia, Canada. General

170 water quality indicators of temperature, dissolved oxygen (DO), specific conductance, and $\mathrm{pH}$

171 were made in situ for each sample collection event with a YSI600 handheld water quality sonde

172 (YSI Inc., Yellow Springs, Ohio, United States). The sonde was calibrated as per manufacturer's 
173 specifications. Conventional wastewater quality parameters that were analyzed for each sample

174 included five-day carbonaceous biochemical oxygen demand $\left(\mathrm{CBOD}_{5}\right)$, total suspended solids

175 (TSS), Escherichia coli (E. coli), total nitrogen (TN), total ammonia nitrogen (TAN), and total

176 phosphorus (TP). These parameters were measured in accordance with standard methods

177 (APHA, 2012). Total coliform and E. coli were enumerated with membrane filtration and

178 Millipore mColiBlue24 broth $^{\circledR}$ as per the standard instructions (Hach Company, Loveland,

179 Colorado, United States). Quantification of a suite of 21 metals was conducted for all water

180 samples with inductively coupled-mass spectrometry (ICP-MS) in accordance with APHA 181 (2012).

\subsubsection{Antibiotic analysis}

183 The samples were analyzed for a suite of antibiotics once a month at Acadia University in Nova 184 Scotia, Canada. These included: amoxicillin, cefaclor, cefprozil, cefdinir, levofloxacin, 185 ciprofloxacin, azithromycin, clindamycin, clarithromycin, and triclocarban. See Supplemental 186 Information for information on sample preparation and QAQC.

\subsubsection{Genetic analysis}

188 Approximately $25 \mathrm{~mL}$ of the raw wastewater and septic tank effluent (STE) water samples were 189 filtered through a $0.45 \mu \mathrm{m}$ pore size filter using a Millipore Vacuum Manifold and sterilized 190 magnetic filtration funnels. Likewise, a measured volume of approximately $400 \mathrm{~mL}$ was filtered 191 for the SF effluent. The DNA retained on the filters from the water samples was extracted with 192 Qiagen DNeasy Powersoil Kits (Qiagen Inc., Toronto, Ontario, Canada). Following filtration, 193 each filter was immediately placed in a Powerbead tube and subsequent processing steps were 194 followed in accordance with manufacturer's specifications. Quantitative real-time polymerase 195 chain reaction (qPCR) was used to enumerate the gene copy numbers of the following suite of 
196

gene markers: class I integrase gene (int1), sulfonamide resistance genes (sul1 and sul2), methicillin resistance gene (mecA), vancomycin type A resistance gene (vanA), fluoroquinolone resistance gene (qnrS), macrolide-lincosamide-streptogramin type B resistance gene (ermB), tetracycline resistance gene (tetO), and class A $\beta$-lactamase genes (bla $a_{T E M}$ and bla $a_{C T X-M}$ ). The nine ARG markers were selected to represent the genes that confer resistance to the common clinically prescribed antibiotics as identified by the Government of Canada (2016). The int1 gene was analyzed because it is commonly associated with MGEs and genes which confer resistance to antibiotics (Gillings et al., 2015). The HF183 is a Bacteroides 16 S ribosomal ribonucleic acid (rRNA) gene marker that is human-specific and is used to measure human fecal pollution in water environments (Seurinck et al., 2005); it was included in the gene scan to assess its utility as an indicator marker of elevated presence of ARGs. The HF183 gene marker was assessed as per the methodology described by McConnell et al. (2018a). The gene marker suite was quantified using TaqMan qPCR on a Bio-Rad CFX96 Touch system (Bio-Rad, Herculer, California, United States). The bacterial 16S rRNA gene copies were enumerated for each sample with SYBR Green qPCR (Applied Biosystems Inc., Beverly, Massachusetts, United States). A comprehensive description of the qPCR method development is found in Neudorf et al. (2017). The primer and hydrolysis TaqMan probe sequences and cycling conditions are provided in the Supplemental Information (Table S1). The limit of quantification (LOQ) and limit of detection (LOD) of the gene markers are summarized in Table S2 in the Supplemental Information.

\subsubsection{Cell-associated and cell-free DNA analysis}

Cell-associated and cell-free DNA was enumerated for a small sub-set of the samples collected in July 2018 according to a slightly modified version of a procedure introduced and described by 
218 Zhang et al. (2018). Additional details on the methodology are provided in the Supplemental

219 Information (Figure S5).

2.2.5. Antibiotic resistant bacteria enumeration

221 Total bacteria and antibiotic resistant bacteria in the raw wastewater, STE, and SFs samples from

222 July 16 and July 23, 2018, were enumerated on agar plates containing no antibiotics (i.e., total

223 bacteria, control) and concentrations of either $50 \mathrm{mg} / \mathrm{L}$ sulfamethoxazole, $50 \mathrm{mg} / \mathrm{L}$ erythromycin,

224 or $10 \mathrm{mg} / \mathrm{L}$ tetracycline (Mao et al., 2015). A spot plating method was used where three $20 \mu \mathrm{L}$

225 drops (for a total volume of $60 \mu \mathrm{L}$ ) of serially diluted raw wastewater, STE, and SF effluent

226 samples were placed on tryptone soy agar (TSA, Oxoid Ltd., Basingstoke, Hampshire, United

227 Kingdom) plates, with or without each antibiotic at the defined concentrations, and incubated at

$22830^{\circ} \mathrm{C}$ for 24 hours. After incubation, the number of colonies were counted and recorded as log

229 colony forming unit (CFU) per mL.

$230 \quad$ 2.3. Sodium bromide tracer tests

231 Sodium bromide $(\mathrm{NaBr})$ tracer tests were conducted on the SFs on July 30, 2018 during a dry

232 weather period. These tests were conducted as per the methodology described in the

233 Supplemental Information.

234 2.4. Statistical analysis

235 One-way analysis of variance (ANOVA) tests were performed on the absolute abundances of

236 ARGs from the SF effluent over the study period to assess statistical difference at $\mathrm{p}<0.05$. A

237 Shapiro-Wilk normality tested normality with the non-normality assigned at $\mathrm{p}<0.05$. The

238 Brown-Forsythe method assessed for equal variance with significant differences in variances

239 assigned at $\mathrm{p}<0.05$. When the assumption of normality was not met, a Kruskal-Wallis ANOVA

240 on ranks was performed with significant difference between treatments assigned at $\mathrm{p}<0.05$. A 
241 Tukey test was performed to assess significant differences between SF effluent absolute

242 abundances and significance attributable at $\mathrm{p}<0.05$. The same statistical analysis was performed

243 on the relative abundances of ARGs with addition of the raw wastewater and STE sample data.

244 Throughout, $\bar{x}$ denotes mean of the sample. The potential for correlations between ARGs and

245 other water quality indicators was of interest to assess whether there are water quality indicators

246 associated with ARGs. To address this, a principal component analysis (PCA) was conducted on

247 the 10-sample dataset with gene marker concentrations, conventional wastewater indicators, and

248 metals concentrations in the raw wastewater, STE, and sand filter effluent. The metals that were

249 excluded from the analysis included selenium (Se), silver (Ag), cadmium (Cd), antimony (Sb),

250 cesium (Ce), and uranium (U), due to most measurements being below the detection limit (see

251 Supplemental Information for metals data). The PCA data was log-transformed and analysed as a

252 correlation matrix. The statistical analysis was performed with SigmaPlot version 13.0 statistical

253 software (Systat software, Inc., San Jose, California, United States).

254 3. Results and discussion

255 3.1. Conventional parameters

256 The sand filters were effective at removal of the conventional wastewater parameters that were

257 analyzed (Table 1). The average removal efficiencies for the filters ranged from $99-100 \%$ for

$258 \mathrm{CBOD}_{5}, 91-100 \%$ for TSS, $5.2-6.7 \log$ for E. coli, $27-37 \%$ for TN, and $-1-60 \%$ for TP

259 (negative value indicates net phosphorus production), which compared well with findings on this

260 specific system by Wilson et al. (2011). Wilson et al. (2011) reported removal efficiencies of: 97

$261-98 \%$ for $\mathrm{CBOD}_{5}, 82-97 \%$ for TSS, $4.3-5.2 \log$ reduction for E. coli, $41-57 \%$ for TN, and

$26244-93 \%$ for TP. Wilson et al. (2011) attributed the primary removal mechanisms to physical

263 filtration processes from the sand media and biological removal processes within the biological 
264 zone (i.e., biological mat) at the interface of the gravel distribution trench and the sand filter 265 media. The slight improvement in $\mathrm{CBOD}_{5}$, TSS, and E. coli removal efficiencies may be 266 attributed to a matured biological zone over the past 7 years. Development of a biological mat is 267 characterized by a physical clogging of the pores in the distribution interface of a soil-adsorption 268 system; formation of this zone begins within the first few months of the operation of the soil269 adsorption system and gradually reaches an equilibrium (Beal et al., 2005). 
270 Table 1. Summary of conventional wastewater parameter results presented as mean values \pm standard deviation $(\mathrm{n}=10)$.

\begin{tabular}{|c|c|c|c|c|c|c|c|c|c|}
\hline $\begin{array}{l}\text { Sample } \\
\text { description }\end{array}$ & $\begin{array}{l}\mathrm{CBOD}_{5} \\
(\mathrm{mg} / \mathrm{L})\end{array}$ & $\begin{array}{l}\text { TSS } \\
(\mathrm{mg} / \mathrm{L})\end{array}$ & $\begin{array}{l}{\text { E. } \text { coli }^{\mathrm{a}}}^{(\mathrm{CFU} / 100 \mathrm{~mL})}\end{array}$ & $\begin{array}{l}\mathrm{TN} \\
(\mathrm{mg} / \mathrm{L})\end{array}$ & $\begin{array}{l}\text { TAN } \\
(\mathrm{mg} / \mathrm{L})\end{array}$ & $\begin{array}{l}\mathrm{TP} \\
(\mathrm{mg} / \mathrm{L})\end{array}$ & $\begin{array}{l}\text { Temp. } \\
\left({ }^{\circ} \mathrm{C}\right)\end{array}$ & $\begin{array}{l}\mathrm{DO} \\
(\mathrm{mg} / \mathrm{L})\end{array}$ & $\mathrm{pH}$ \\
\hline Raw & $343 \pm 138$ & $295 \pm 141$ & $\begin{array}{l}3.4 \times 10^{6} \\
3.5 \times 10^{6}\end{array}$ & $46 \pm 23$ & $45 \pm 20$ & $6.5 \pm 2.9$ & $15.9 \pm 1.5$ & $4.5 \pm 2.7$ & $7.4 \pm 0.2$ \\
\hline STE & $219 \pm 148$ & $182 \pm 128$ & $\begin{array}{l}3.3 \times 10^{5} \\
5.8 \times 10^{5}\end{array}$ & $54 \pm 24$ & $62 \pm 26$ & $9.6 \pm 9.7$ & $17.1 \pm 1.2$ & $2.8 \pm 2.2$ & $6.6 \pm 0.1$ \\
\hline SF1 & $2 \pm 1$ & $25 \pm 20$ & $1 \pm 12$ & $30 \pm 6$ & $0.1 \pm 0.1$ & $2.6 \pm 3.2$ & $16.5 \pm 1.8$ & $8.1 \pm 1.2$ & $6.1 \pm 0.4$ \\
\hline SF2 & $2 \pm 1$ & $5 \pm 10$ & $1 \pm 0.6$ & $30 \pm 4$ & $0.2 \pm 0.3$ & $3.3 \pm 1.3$ & $16.3 \pm 1.8$ & $10.3 \pm 1.3$ & $6.6 \pm 0.2$ \\
\hline SF3 & $2 \pm 1$ & $2 \pm 2$ & $1 \pm 10$ & $29 \pm 6$ & $0.1 \pm 0.1$ & $5.8 \pm 5.0$ & $16.2 \pm 1.8$ & $10.1 \pm 1.2$ & $6.4 \pm 0.3$ \\
\hline SF4 & $2 \pm 1$ & $1 \pm 1$ & $1 \pm 2$ & $33 \pm 9$ & $0.1 \pm 0.1$ & $1.7 \pm 1.0$ & $16.6 \pm 1.7$ & $9.9 \pm 1.3$ & $6.0 \pm 0.2$ \\
\hline SF5 & $2 \pm 1$ & $4 \pm 3$ & $4 \pm 7$ & $31 \pm 5$ & $0.1 \pm 0.1$ & $4.3 \pm 3.5$ & $16.0 \pm 1.5$ & $10.1 \pm 1.1$ & $6.0 \pm 0.3$ \\
\hline SF6 & $2 \pm 1$ & $3 \pm 3$ & $19 \pm 339$ & $29 \pm 10$ & $0.2 \pm 0.5$ & $6.6 \pm 7.3$ & $16.1 \pm 1.7$ & $9.9 \pm 1.0$ & $6.3 \pm 1.2$ \\
\hline
\end{tabular}

$271 \quad{ }^{\mathrm{a}}$ E.coli data is presented as geometric means. 
273 The HRTs of the sand filters are summarized in Table 2. SF1 had the longest HRT ( 8 days),

274 given that this filter had the lowest hydraulic conductivity as specified in Section 2.1, and was on 275 a shallow slope; however, the deviation from the other filters warranted further examination. To 276 investigate this, SF1 was partially excavated to the interface between the gravel trench and the 277 sand media where the biological mat resided. SF1 was found to be partially clogged, with 278 saturated conditions and ponded water within the biological mat (see Figure S4 in Supplemental 279 Information). The finer grain size and low slope may have increased its vulnerability to failure. 280 Saturated conditions in OWTS have been known to present a higher risk of conveyance of 281 pathogens and ensuing human exposure (Beal et al., 2005). Average flows from each filter over 282 the study period ranged from 108 to 152 L per day (See Figure S8 in Supplemental Information 283 for the hydrographs over the study period).

284 Table 2. Summary of hydraulic characteristics of the sand filters determined from the bromide 285 tracer tests.

\begin{tabular}{|c|c|c|c|c|c|c|}
\hline Filter ID & Grain size & Slope (\%) & $\begin{array}{l}\mathrm{HRT} \\
\text { (days) }\end{array}$ & $\begin{array}{l}\text { Mass } \\
\text { recovery } \\
\text { (\%) }\end{array}$ & $\begin{array}{l}\text { Time to } \\
\text { peak (hrs) }\end{array}$ & $\begin{array}{l}\text { Variance } \\
\text { (dimension } \\
\text { less) }\end{array}$ \\
\hline SF1 & Fine & 5 & 8 & $150^{\mathrm{a}}$ & 154 & 0.16 \\
\hline SF2 & Medium & 5 & 4 & 73 & 36 & 0.79 \\
\hline SF3 & Coarse & 5 & 5 & 79 & 42 & 0.73 \\
\hline SF4 & Fine & 30 & 6 & 102 & 60 & 0.36 \\
\hline SF5 & Medium & 30 & 4 & 89 & 36 & 0.75 \\
\hline
\end{tabular}




\begin{tabular}{lllllll}
\hline SF6 & Coarse & 30 & 3 & 86 & 30 & 0.84
\end{tabular}

$286{ }^{a}$ The mass recovery for SF1 was overestimated likely due to hydraulic failure of the filter and 287 preferential flow in this filter (see Figure S6 in Supplemental Information).

\subsection{Raw wastewater and septic tank effluent}

\subsubsection{Absolute and relative gene abundances}

290 All the gene markers were present in the raw wastewater and STE, with absolute abundances 291 well above the LOQs for all gene markers except for vanA and mecA (Figure 2). The 292 vancomycin resistance gene, vanA, and in most samples the methicillin resistance gene, mecA 293 were close to or below the LOQs. These two ARGs were not plotted in Figures 2 and 3, due to 294 low levels (see Supplemental Information spreadsheet). The most abundant ARGs within the raw 295 wastewater were $\mathrm{ermB}(\bar{x}=6.5 \pm 0.7 \log$ gene copies/mL), qnrS $(\bar{x}=6.2 \pm 0.4 \log$ gene 296 copies $/ \mathrm{mL})$, and tetO $(\bar{x}=5.7 \pm 0.4 \log$ gene copies $/ \mathrm{mL})$. Overall, the septic tank removed 297 minimal amounts of the gene markers from the effluent stream. Therefore, the most abundant 298 ARGs within the STE were ermB $(\bar{x}=5.9 \pm 0.8 \log$ gene copies $/ \mathrm{mL})$, and sul1 $(\bar{x}=5.2 \pm 0.6 \log$ 299 gene copies/mL), tetO $(\bar{x}=5.1 \pm 0.3 \log$ gene copies/mL). These ARG abundances in the STE 300 were comparable in order of magnitude to raw and primary treated wastewater from other studies 301 (Czekalski et al., 2012; McConnell et al., 2018b). In comparison to raw wastewater samples, 302 there was no significant enrichment of ARGs in the STE (Figure 3). The highest relative 303 abundances of ARGs in the STE were ermB $(\bar{x}=-2.5 \pm-2.3$ log gene copies for ermB/16S 304 rRNA), and sul1 ( $\bar{x}=-3.4 \pm-3.4$ log gene copies for sul1/16S rRNA). 

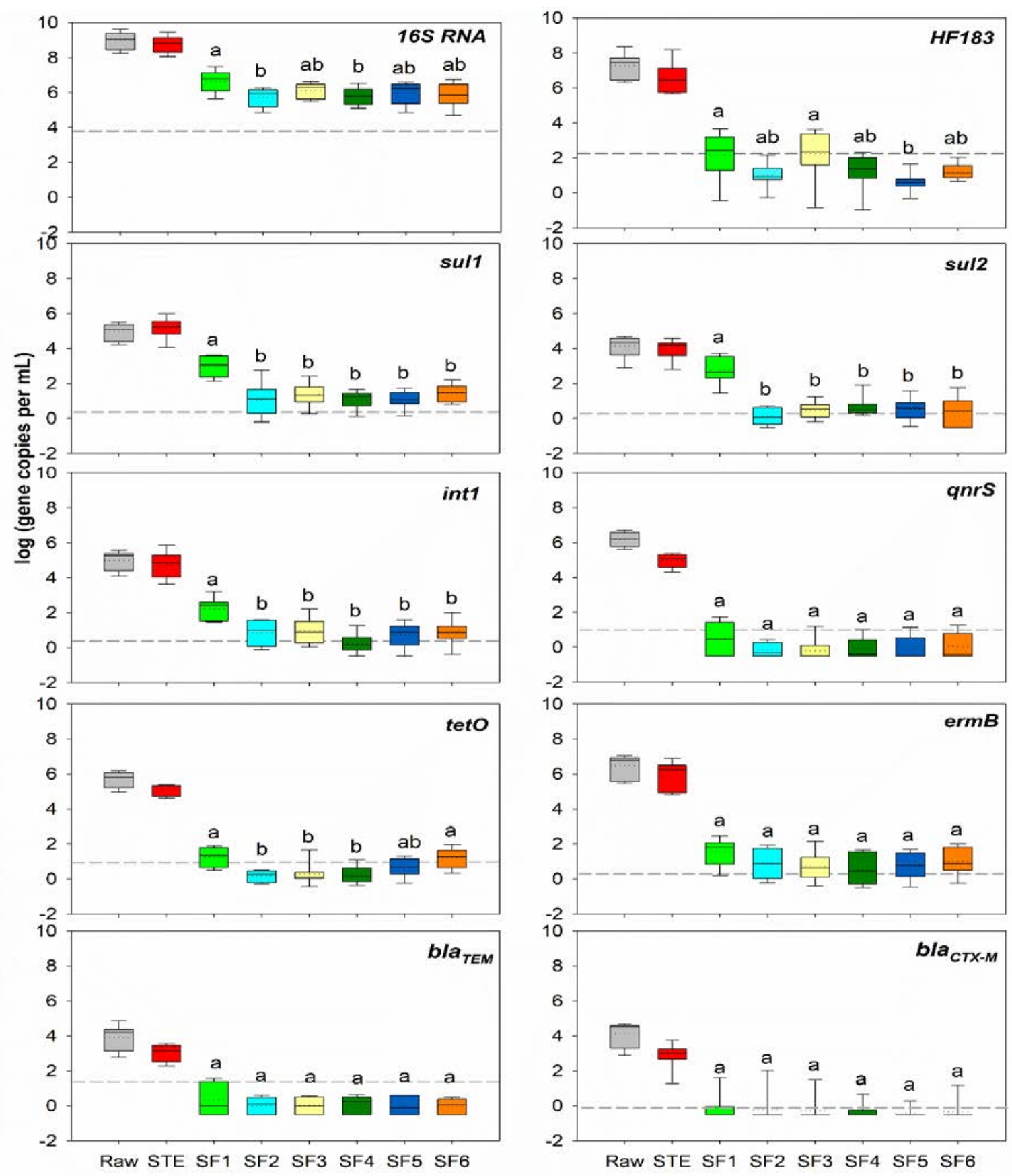

Figure 2. Absolute abundances of gene markers in the raw wastewater, septic tank effluent (STE), and sand filter (SF) $1-6$ for the duration of the study $(n=10)$. The middle lines represent the median values, the dotted lines represent the means, the bottom and top of the boxes represent the $25^{\text {th }}$ and $75^{\text {th }}$ percentiles, and the whiskers represent the $10^{\text {th }}$ and $90^{\text {th }}$ percentile of the gene concentrations. The dashed line represents the limit of quantification for the sand filter effluent. Difference in letters denotes significant difference of the gene absolute abundances at $\mathrm{p}$ $<0.05$ for the Tukey test. The raw wastewater and septic tank effluent samples were not analyzed statistically as the differences in sand filter performance were of primary interest. 

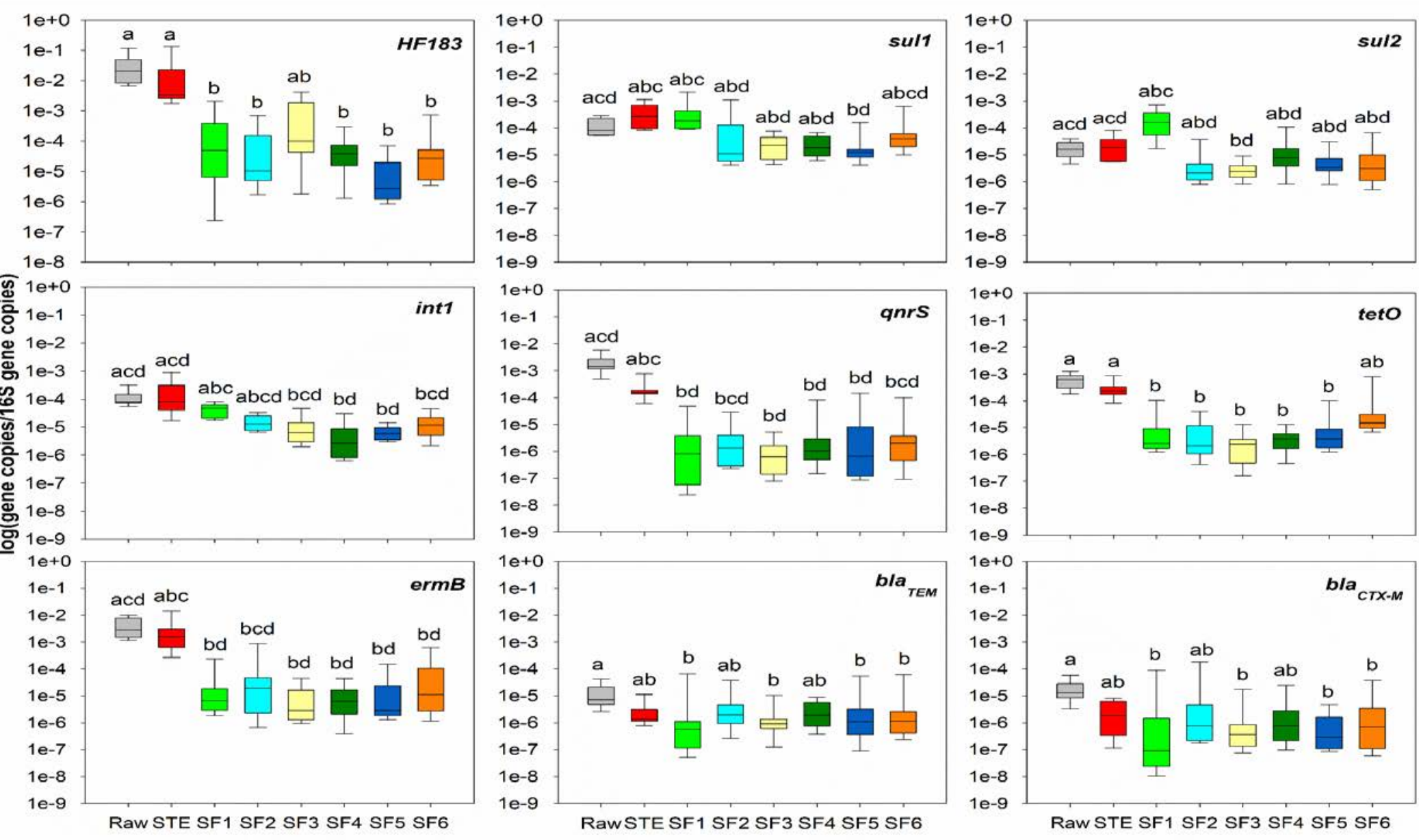

Figure 3. Relative abundances of gene markers in the raw wastewater, septic tank effluent (STE), and sand filters (SF) $1-6$ for the duration of the study $(\mathrm{n}=10)$. The middle lines represent the median values, the dotted lines represent the means, the bottom and top of the boxes represent the $25^{\text {th }}$ and $75^{\text {th }}$ percentiles, and the whiskers represent the $10^{\text {th }}$ and $90^{\text {th }}$ percentile of the gene concentrations. Difference in letters denotes significant difference between the gene absolute abundances at $\mathrm{p}<0.05$ for the Tukey test. 


\subsection{Filter gene marker removal performance}

\subsubsection{Absolute and relative gene abundances}

321 The sand filters performed effectively for the removal of ARGs from the STE as demonstrated

322 with the absolute abundances illustrated in Figure 2. There were few significant differences 323 between the filters apart from SF1, which removed significantly $(\mathrm{p}<0.05)$ lower amounts of the

324 ARGs. The effluent from all sand filters contained medians below LOQ levels for $q n r S, b l a_{T E M}$, 325 and mecA, and below LOD for vanA. No seasonal trends in ARG abundances were observed 326 over the study period as shown in the Supplemental Information Table S5 in the spreadsheet.

327 Treatment of the STE in the SFs $2-6$ resulted in the following average absolute removal of 328 ARGs: 2.6 to 3.0 log removal for $16 \mathrm{~S}$ rRNA, 4.3 to 6.0 log removal for HF183, 3.7 to 4.1 log 329 removal for sul1, 3.3 to $3.8 \log$ removal for sul2, 3.8 to $4.5 \log$ removal for int1, 4.9 to $5.2 \log$ 330 removal for $q n r S, 3.9$ to 4.9 log removal for tetO, 4.9 to $5.4 \log$ removal for ermB, 2.9 to $3.0 \log$ 331 removal for bla $a_{T E M}$, and 3.1 to 3.3 log removal for bla $a_{C T X-M}$.

332 Due to the decreased performance of SF1, it was considered separately from the aforementioned 333 ranges with absolute removals of: $\bar{x}=2.1 \log$ removal for $16 \mathrm{~S}$ rRNA, $\bar{x}=4.4 \log$ for $H F 183, \bar{x}$ $334=2.2 \log$ removal for sul1, $\bar{x}=1.2 \log$ removal for sul2, $\bar{x}=2.5 \log$ removal for int1, $\bar{x}=4.5 \log$ 335 removal for $q n r S, \bar{x}=3.9 \log$ removal for tetO, $\bar{x}=4.4 \log$ removal for ermB, $\bar{x}=2.7 \log$ 336 removal for $b l a_{T E M}$, and $\bar{x}=3.0 \log$ removal for bla $a_{C T X-M}$. The lack of difference in the absolute 337 abundances of the gene markers between the sand filters (except for SF1) suggested that the 338 grain sizes in the three different sand mediums and two different slopes had little effect on the 339 removal of the gene markers. It should be noted that the effective size $\left(D_{10}\right)$ value of the three 340 sand medias ranged from $0.12-0.18 \mathrm{~mm}$. Therefore, the smaller particle sizes of the media were 341 similar, which may have contributed to similar gene removal efficiencies. 
342 As noted above, the exception was SF1, which effected significantly $(\mathrm{p}<0.05)$ less removal for 343 sul1, sul2, and int1 than all the other sand filters, resulting in levels that were well above the 344 LOQ for these three ARGs. Likely, the decrease in attenuation of ARGs in SF1 was due to the 345 suspected hydraulic failure of the filter. From an engineering perspective, this may suggest that 346 an OWTS like SF1 with low hydraulic conductivity configurations on a shallow slope may 347 present greater risk of failure and ARG breakthrough as they age.

348 The HF183 markers were generally below the LOQ except for SF1 and SF3 (Figure 2). This 349 contrasts with the trends in some of the ARGs, for instance sul1 and ermB have median absolute 350 abundances consistently above the LOQs. Therefore, the utility of HF183 as an indicator for 351 elevated ARGs associated with human fecal contamination may be useful, but not all 352 encompassing.

353 In general, the relative abundances of the gene markers in filter effluent were significantly lower 354 than in the raw wastewater and STE ( $<<0.05$; Figure 3 ). Some exceptions to this trend were 355 evident, which included SF1 showing significant $(\mathrm{p}<0.05)$ enrichments of sul1, sul2, and int1 356 compared to the majority of the other sand filters. This enrichment of gene markers in SF1 is 357 likely attributable to the hydraulic failure of this filter, which affected treatment performance. 358 Overall, the relative abundances of the gene markers in the sand filter effluent represented a 359 small percentage of the overall 16S rRNA gene abundances. These results suggest minimal gene 360 marker enrichment when comparing the effluent samples, except for SF1 for sul1, sul2, and int1. 361 Persistence of sul genes have also been reported in other types of wastewater treatment systems 362 (McConnell et al., 2018b; Gao et al., 2012). 
364 The treatment train was analyzed for ARB twice on July 16 and July 23, 2018, respectively 365 (Figure 4). Bacteria that were resistant to antibiotics that were plated separately (i.e., 366 sulfamethoxazole, erythromycin, tetracycline) were present at comparable magnitudes ranging 367 from 1.6 to $2.8 \log \mathrm{CFU} / \mathrm{mL}$ in the SF effluent, down from levels of $\sim 5 \log \mathrm{CFU} / \mathrm{mL}$ in the raw 368 wastewater. E. coli counts for the same sample events were low ( $<1.2 \log$ CFU/100mL) for the 369 SF effluent, which indicated that the bacteria carrying the resistance to these antibiotics were 370 likely different species than E. coli. Sul and erm which confer resistance to sulfamethoxazole and 371 erythromycin were detected with absolute abundances above the LOQs in the sand filter effluent. 372 This suggests that a portion of the sul and erm genes in the effluent would be associated with live 373 bacteria. The qPCR analyses of a subset of the ARB colonies confirmed the presence of the 374 relevant ARG markers (sul1 and sul2, ermB, and tetO). 


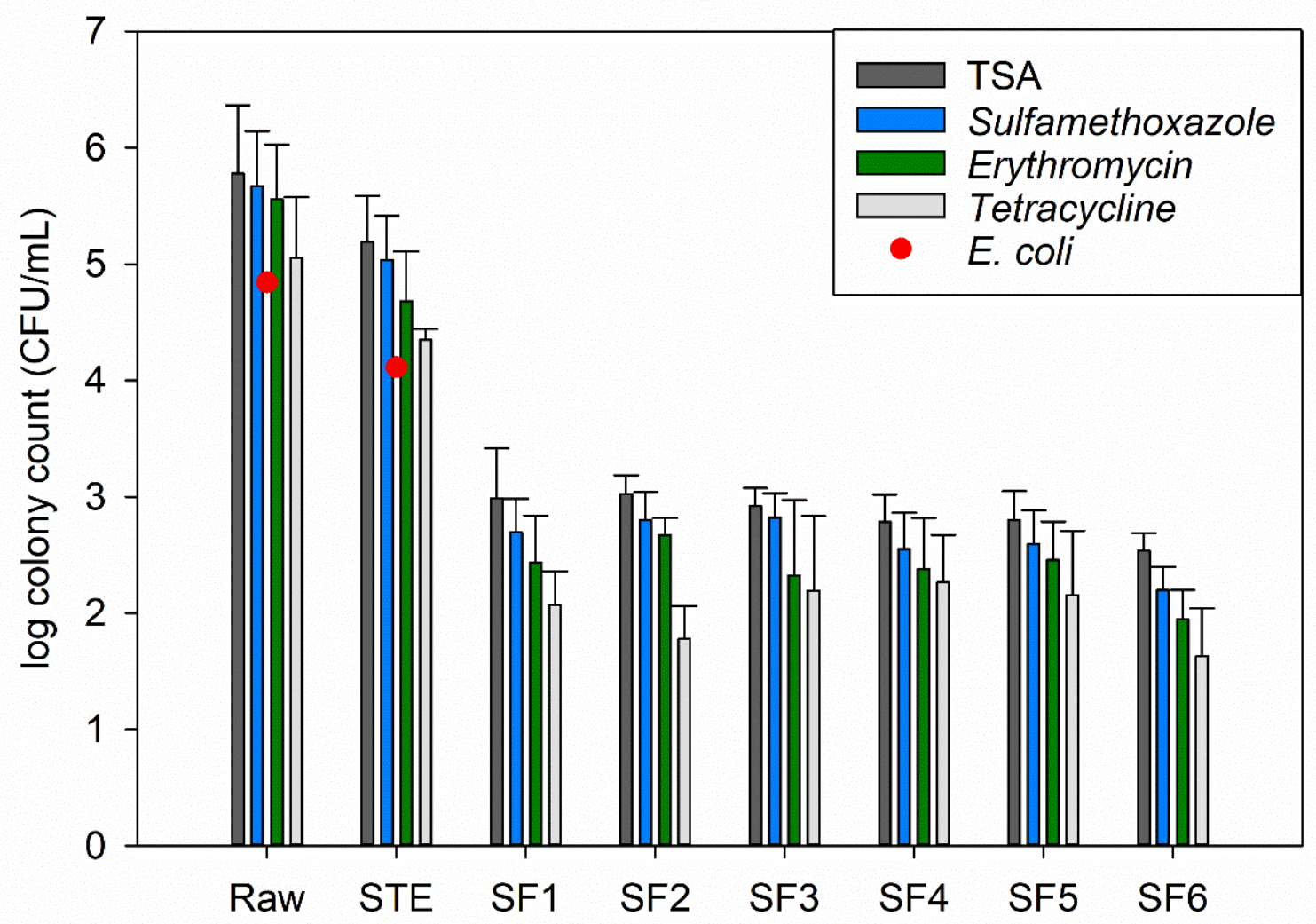

375

376
Figure 4. Geometric mean of total and antibiotic resistant bacteria in samples of raw wastewater, septic tank effluent (STE), and sand filter (SF) effluents (sampled on July 16 and 23, 2018, n = 4). The error bars represent one standard deviation. The E. coli is presented as the geometric mean of two samples collected on July 16 and 23, 2018. The E. coli concentrations for the SF effluent were all below $1 \mathrm{CFU} / \mathrm{mL}$.

3.6. Correlations between gene markers and water quality parameters

There was a positive correlation between the gene markers and the conventional wastewater quality indicators (Figure 5a). E. coli showed a positive correlation to the gene markers, which is anticipated as bacteria such as E. coli can house selected gene markers intracellularly. Several heavy metals were positively correlated with the gene markers, which included chromium (Cr), barium $(\mathrm{Ba})$, and copper $(\mathrm{Cu})$, which may indicate co-selection for resistance to metals and ARGs in bacteria. Chromium and copper were elevated in the raw wastewater and STE which may have been an artifact of metals originating from household plumbing fixtures. Co-selection 
389 of ARGs and heavy metal resistance genes in municipal wastewater have been observed by Di

390 Cesare et al. (2016), and specifically co-selection of tetracycline and copper was observed by 391 Amachawadi et al (2013). Sodium (Na), magnesium (Mg), calcium (Ca) and potassium (K) were

392 observed to be negatively correlated with the gene markers and conventional wastewater quality 393 indicators. This inverse relationship may be explained by relatively lower concentrations 394 observed for these cations in the raw wastewater and STE, and an elevated concentration in the 395 sand filter effluent. Calcium carbonate $\left(\mathrm{CaCO}_{3}\right)$ dissolution is characteristic of septic field 396 environments as a buffer for $\mathrm{NH}_{4}{ }^{+}$oxidation, which results in increased $\mathrm{Ca}^{2+}$ concentrations in 397 the effluent, and other major cations may also exhibit similar mineral dissolution, or cation 398 exchange reactions (Wilhelm et al., 1994). The scores plot in Figure 5b shows the overall 399 difference in concentrations between the raw wastewater and STE samples; which were 400 generally grouped together, and the sand filter samples which were clustered together, except for 401 SF1. This confirms the degree of system characterization ( $\mathrm{n}=10$ sample events) was adequate to 402 capture variability in water quality. 
a)

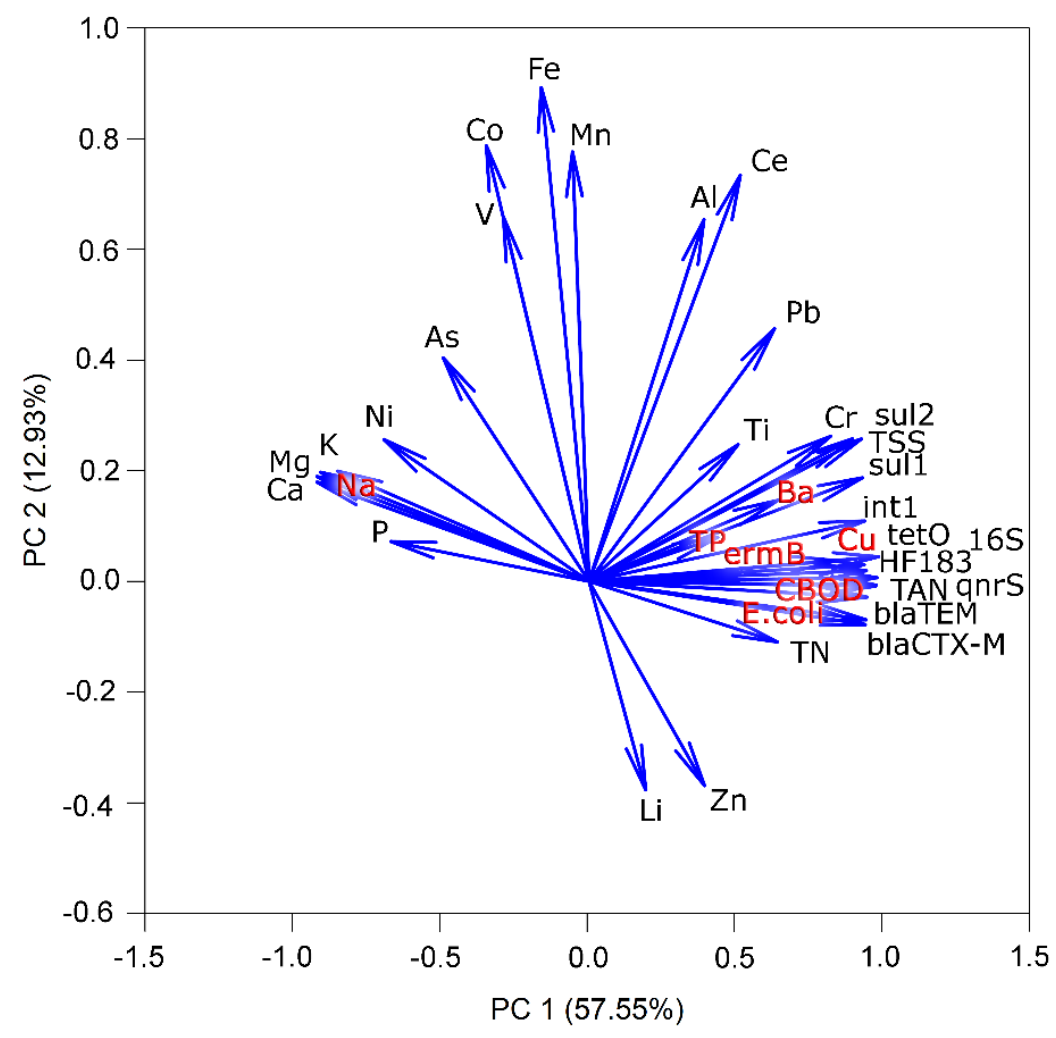

b)

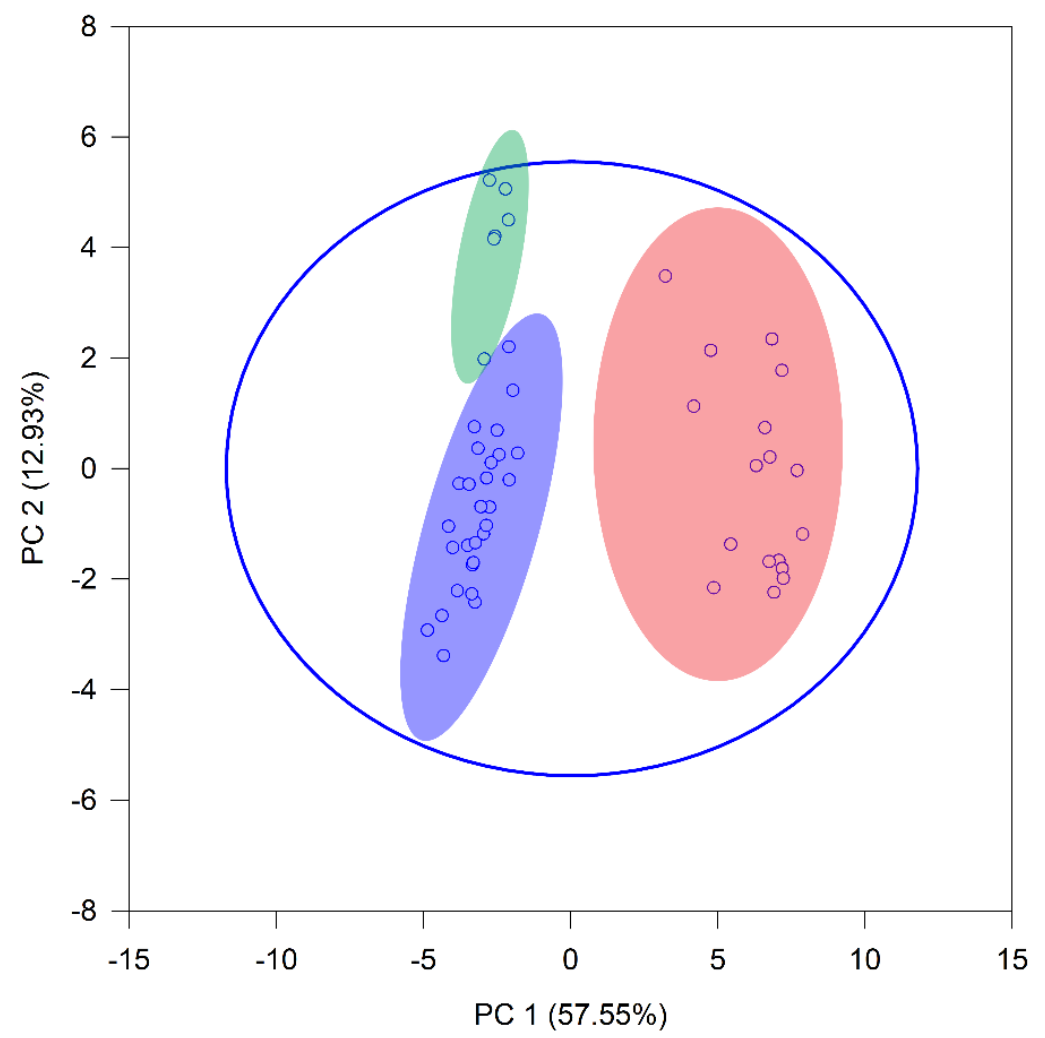

Figure 5. Principal component analysis (PCA) of the gene marker concentrations and water quality indicators along the treatment train. This illustrates the: a) loadings plot of the gene markers and other parameters ( $n=10$ sample events), use of red text is for contrast; and b) scores plot of the PCA results of the wastewater sampling. Ellipses denote groupings of scores of sand filters $2-6$ (blue); sand filter 1 (green); and the raw wastewater and septic tank effluent samples (red). The numbers in brackets represent the percentage of variance described in the dataset by the first and second components. 
410 The enumeration of total, cell-associated, and cell-free DNA for each gene marker within the

411 treatment train are presented in Table 3. Cell-associated DNA represented the greatest

412 apportionment of DNA for all the gene markers and throughout the treatment train. All cell-free

413 DNA observed in the analysis were either below LOQ or LODs. The raw wastewater and STE

414 had negligible apportionment of cell-free DNA, and the sand filters contained cell-free DNA

415 levels below the LODs, including the poorly performing SF1. This indicates that the gene

416 markers that were measured throughout the treatment train resided primarily inside bacterial cells

417 (i.e., intracellularly). This finding indicates that this type of treatment system is at low risk of

418 spreading cell-free ARGs. 
419 Table 3. Summary of average gene marker concentrations in the total, cell associated, and cell-free DNA fractions for raw

420 wastewater, septic tank effluent (STE) and sand filters (SF) 1 - 3 samples collected on July 16 and July 23, 2018. Bolded numbers

421 indicate absolute abundances above the LOQ, italicized numbers are below the LOQ, $<\mathrm{DL}$ means are below the detection limit .

\begin{tabular}{|c|c|c|c|c|c|c|c|c|c|c|c|c|c|c|c|}
\hline & \multicolumn{15}{|c|}{ Sample ID } \\
\hline \multirow[b]{2}{*}{$\begin{array}{l}\text { Gene } \\
\text { marker }\end{array}$} & Raw & & & STE & & & SF1 & & & SF2 & & & SF3 & & \\
\hline & Total & $\begin{array}{l}\text { Cell- } \\
\text { associa } \\
\text { ted }\end{array}$ & $\begin{array}{l}\text { Cell- } \\
\text { free }\end{array}$ & Total & $\begin{array}{l}\text { Cell- } \\
\text { associa } \\
\text { ted }\end{array}$ & $\begin{array}{l}\text { Cell- } \\
\text { free }\end{array}$ & Total & $\begin{array}{l}\text { Cell- } \\
\text { associa } \\
\text { ted }\end{array}$ & $\begin{array}{l}\text { Cell- } \\
\text { free }\end{array}$ & Total & $\begin{array}{l}\text { Cell- } \\
\text { associa } \\
\text { ted }\end{array}$ & $\begin{array}{l}\text { Cell- } \\
\text { free }\end{array}$ & Total & $\begin{array}{l}\text { Cell- } \\
\text { associa } \\
\text { ted }\end{array}$ & $\begin{array}{l}\text { Cell- } \\
\text { free }\end{array}$ \\
\hline
\end{tabular}

Log gene copies per $\mathrm{mL}$

\begin{tabular}{|c|c|c|c|c|c|c|c|c|c|c|c|c|c|c|c|}
\hline 16S rRNA & 9.5 & 8.5 & 1.4 & 9.2 & 8.0 & 1.1 & 6.8 & 6.4 & $<\mathrm{DL}$ & 6.3 & 5.3 & 0.8 & 6.4 & 5.7 & $<\mathrm{DL}$ \\
\hline HF183 & 6.7 & 6.4 & 0.6 & 5.8 & 5.6 & 0.5 & 2.1 & $<\mathrm{DL}$ & $<\mathrm{DL}$ & 3.0 & 2.3 & $<\mathrm{DL}$ & 2.6 & 1.1 & $<\mathrm{DL}$ \\
\hline sul1 & 5.1 & 4.3 & 1.1 & 4.5 & 4.0 & 1.2 & 3.0 & 2.4 & $<\mathrm{DL}$ & 1.3 & $<\mathrm{DL}$ & $<\mathrm{DL}$ & 1.9 & $<\mathrm{DL}$ & $<\mathrm{DL}$ \\
\hline sul2 & 4.5 & 3.8 & $<\mathrm{DL}$ & 4.1 & 2.8 & 1.0 & 3.0 & 2.4 & $<\mathrm{DL}$ & $<\mathrm{DL}$ & $<\mathrm{DL}$ & $<\mathrm{DL}$ & 1.2 & $<\mathrm{DL}$ & $<\mathrm{DL}$ \\
\hline int1 & 5.6 & 4.5 & 1.1 & 4.1 & 3.6 & $<\mathrm{DL}$ & 2.7 & 1.7 & $<\mathrm{DL}$ & $<\mathrm{DL}$ & $<\mathrm{DL}$ & $<\mathrm{DL}$ & 1.5 & $<\mathrm{DL}$ & $<\mathrm{DL}$ \\
\hline$q n r S$ & 6.1 & 5.7 & $<\mathrm{DL}$ & 5.0 & 4.2 & $<\mathrm{DL}$ & 3.6 & $<\mathrm{DL}$ & $<\mathrm{DL}$ & 1.7 & $<\mathrm{DL}$ & $<\mathrm{DL}$ & 2.5 & $<\mathrm{DL}$ & $<\mathrm{DL}$ \\
\hline tetO & 5.4 & 5.0 & $<\mathrm{DL}$ & 5.0 & 4.6 & $<\mathrm{DL}$ & $<\mathrm{DL}$ & $<\mathrm{DL}$ & $<\mathrm{DL}$ & $<\mathrm{DL}$ & $<\mathrm{DL}$ & $<\mathrm{DL}$ & $<\mathrm{DL}$ & $<\mathrm{DL}$ & $<\mathrm{DL}$ \\
\hline ermB & 6.1 & 5.6 & $<\mathrm{DL}$ & 5.2 & 4.9 & $<\mathrm{DL}$ & 1.3 & $<\mathrm{DL}$ & $<\mathrm{DL}$ & $<\mathrm{DL}$ & $<\mathrm{DL}$ & $<\mathrm{DL}$ & $<\mathrm{DL}$ & $<\mathrm{DL}$ & $<\mathrm{DL}$ \\
\hline$b l a_{T E M}$ & 3.3 & 2.9 & $<\mathrm{DL}$ & 2.4 & 2.1 & $<\mathrm{DL}$ & 1.1 & $<\mathrm{DL}$ & $<\mathrm{DL}$ & $<\mathrm{DL}$ & $<\mathrm{DL}$ & $<\mathrm{DL}$ & $<\mathrm{DL}$ & $<\mathrm{DL}$ & $<\mathrm{DL}$ \\
\hline$b l a_{C T X-M}$ & 4.0 & 3.0 & $<\mathrm{DL}$ & 2.6 & 2.0 & $<\mathrm{DL}$ & 1.2 & $<\mathrm{DL}$ & $<\mathrm{DL}$ & $<\mathrm{DL}$ & $<\mathrm{DL}$ & $<\mathrm{DL}$ & $<\mathrm{DL}$ & $<\mathrm{DL}$ & $<\mathrm{DL}$ \\
\hline mecA & 1.7 & 1.0 & $<\mathrm{DL}$ & 1.5 & $<\mathrm{DL}$ & $<\mathrm{DL}$ & 1.0 & $<\mathrm{DL}$ & $<\mathrm{DL}$ & $<\mathrm{DL}$ & $<\mathrm{DL}$ & $<\mathrm{DL}$ & $<\mathrm{DL}$ & $<\mathrm{DL}$ & $<\mathrm{DL}$ \\
\hline vanA & $<\mathrm{DL}$ & $<\mathrm{DL}$ & $<\mathrm{DL}$ & $<\mathrm{DL}$ & $<\mathrm{DL}$ & $<\mathrm{DL}$ & $<\mathrm{DL}$ & $<\mathrm{DL}$ & $<\mathrm{DL}$ & $<\mathrm{DL}$ & $<\mathrm{DL}$ & $<\mathrm{DL}$ & $<\mathrm{DL}$ & $<\mathrm{DL}$ & $<\mathrm{DL}$ \\
\hline
\end{tabular}


423 The antibiotic data is in Table S4 of the Supplemental Information. All the antibiotics were

424 detected at least once in the treatment train during the study period. However, during many 425 sample events, several of the antibiotics were not detected. An exception was clindamycin, 426 which was often present in detectable concentrations within the treatment train. In clinical 427 settings, the erm gene can confer resistance to clindamycin as well (Levin et al., 2005). Figure 2 428 shows that ermB was often present above LOQ in the effluent of all the sand filters. 429 Intermittingly, all the antibiotics except for azithromycin, were detected in the sand filter 430 effluents. The chemical stability of antibiotics varies, and some are quick to degrade, which may 431 explain absence in the effluent. There was no direct relationship between antibiotics and ARGs 432 because of the ephemeral nature of the presence of the antibiotics in the influent. The bacteria 433 within the septic tank and biological mat acquire resistance through repeated intermittent 434 exposure over time.

435 4. Conclusions

436 This study demonstrated lateral flow sand filters help to reduce the risk of AMR contamination 437 from OWTS when the hydraulics are properly functioning. Most of the ARGs assessed were 438 removed to below 2 log gene copies per $\mathrm{mL}$ for absolute abundance. Grain size of the filtration 439 media or filter slope had no observable impact on the efficacy of the removal of ARGs except for 440 SF1. The exception of SF1 was due to partial hydraulic failure of the system as evidenced by 441 clogging and water retention on the biological mat. In SF1, significantly ( $<$ 0.05) less removal 442 of sul1, sul2 and int1 were observed in comparison to the other sand filters and therefore 443 elevated ARGs passed through into the filter effluent. This highlights the need for inspection and 444 maintenance of these types of OWTS as they age. 
445 ARGs were mostly found to be present intracellularly in the bacteria as opposed to 446 extracellularly. This type of OWTS system poses low risk of cell-free DNA breakthrough and 447 subsurface transport. ARB, resistant to either sulfamethoxazole, erythromycin, or tetracycline, 448 were observed to undergo an average of $2.3 \log$ reduction across the sand filters. Of importance, 449 the ARB were present in the sand filter effluent with counts ranging from 1.6 to 2.8 log CFU per $450 \mathrm{~mL}$. Concurrently, these samples generally contained non-detectable levels of E. coli. Therefore, 451 sole reliance on E. coli as an indicator may be inadequate to capture the risk of releasing AMR 452 pathogens from mal-functioning OWTS.

453 Future research would be useful to characterize the filter biological mat, specifically examining 454 ARGs and microbial community structure using metagenomics. This would enable further 455 understanding and potential optimization of the biological mat attenuation mechanisms in 456 filtration technology development. Understanding of fate of ARGs in saturated environments 457 would also be useful for further characterization of risk to groundwater resources.

458 Acknowledgments

459 This study was partially supported with funding from Natural Sciences and Engineering 460 Research Council (NSERC) Strategic Grant STPGP 463352 - 14. Doctoral studies funding for 461 JLH was provided by an NSERC PGS D grant. The authors would like to express gratitude to 462 two anonymous reviewers for providing feedback to strengthen the manuscript. The authors also 463 thank the field and lab personnel: Richard Scott, Mary Margaret Letman, Audrey Hiscock, 464 Kathryn Fillmore, Nicole Bell, Katharine Miller, and Cameron Bates. 
466 Anderson, J. C., Joudan, S., Shoichet, E., Cuscito, L. D., Alipio, A. E., Donaldson, C. S., Khan, 467 S., Goltz, D.M., Rudy, M.D., Frank, R.A., Knapp, C. W., Hanson, M.L., Wong., C., 2015. 468 Reducing nutrients, organic micropollutants, antibiotic resistance, and toxicity in rural wastewater effluent with subsurface filtration treatment technology. Ecological Engineering 84, 375-385. https://doi.org/10.1016/j.ecoleng.2015.08.005

Ashbolt, N. J., Amézquita, A., Backhaus, T., Borriello, P., Brandt, K. K., Collignon, P., Coors, 472 A., Finley, R., Gaze, W.H., Heberer, T., Lawrence, J.R., Larsson, D.G.J., McEwen, S.A., Ryan, J.J., Schönfeld, J., Silley, P., Snape, J.R., Van den Eede, C., Topp, E., 2013. Human health risk assessment (HHRA) for environmental development and transfer of antibiotic resistance. Environmental Health Perspectives 121(9), 993-1001. https://doi.org/10.1289/ehp.1206316

Amachawadi, R. G., Scott, H. M., Alvarado, C. A., Mainini, T. R., Vinasco, J., Drouillard, J. S., Nagaraja, T. G., 2013. Occurrence of the transferable copper resistance gene, tcrB, among fecal enterococci of US feedlot cattle fed copper-supplemented diets. Applied and Environmental Microbiology AEM-00503. https://doi.org/10.1128/AEM.00503-13

481

482

483

484

485

486
American Public Health Association (APHA), 2012. Standard methods for the examination of water and wastewater. 22 ed. Water Environment Federation. Washington District of Columbia, United States. Pp. 1496.

Beal, C. D., Gardner, E. A., Menzies, N. W., 2005. Process, performance, and pollution potential: A review of septic tank-soil absorption systems. Soil Research 43(7), 781-802. https://doi.org/10.1071/SR05018 
Berendonk, T. U., Manaia, C. M., Merlin, C., Fatta-Kassinos, D., Cytryn, E., Walsh, F., Bürgmann, H., Sørum, H., Norström, M., Pons, M.-N., Kreuzinger, N., Huovinen, P., Stefani, S., Schwartz, T., Kisand, V., Bacquero, F., Martinez, J.L., 2015. Tackling antibiotic resistance: the environmental framework. Nature Reviews Microbiology 13(5), 310 - 317.

Bürgmann, H., Frigon, D., Gaze, W.H., Manaia, C.M., Pruden, A., Singer, A. C., Smets, B.F., Zhang, T., 2018. Water \& Sanitation: An Essential Battlefront in the War on Antimicrobial Resistance. FEMS Microbiology Ecology 94(9), https://doi.org/10.1093/femsec/fiy101

Carroll, S., Hargreaves, M., Goonetilleke, A., 2005. Sourcing faecal pollution from onsite wastewater treatment systems in surface waters using antibiotic resistance analysis. Journal of Applied Microbiology 99(3), 471-482. https://doi.org/10.1111/j.1365-

\subsubsection{X}

Chen, H., Zhang, M., 2013. Occurrence and removal of antibiotic resistance genes in municipal wastewater and rural domestic sewage treatment systems in eastern China. Environment International 55, 9-14. https://doi.org/10.1016/j.envint.2013.01.019

Conn, K. E., Lowe, K. S., Drewes, J. E., Hoppe-Jones, C., Tucholke, M. B., 2010. Occurrence of pharmaceuticals and consumer product chemicals in raw wastewater and septic tank effluent from single-family homes. Environmental Engineering Science 27(4), 347-356. https://doi.org/10.1089/ees.2009.0364

Crane, S. R., Moore, J. A., 1984. Bacterial pollution of groundwater: a review. Water, Air, and Soil Pollution 22(1), 67-83.

Czekalski, N., Berthold, T., Caucci, S., Egli, A., Bürgmann, H., 2012. Increased levels of multiresistant bacteria and resistance genes after wastewater treatment and their 
dissemination into Lake Geneva, Switzerland. Frontiers in Microbiology 3(106) https://doi.org/10.3389/fmicb.2012.00106

511 Davies, J., Davies, D., 2010. Origins and evolution of antibiotic resistance. Microbiology and Molecular Biology Reviews 74(3), 417-433. https://doi.org/10.1128/MMBR.00016-10

513

Depardieu, F., Podglajen, I., Leclercq, R., Collatz, E., Courvalin, P., 2007. Modes and modulations of antibiotic resistance gene expression. Clinical Microbiology Reviews 20(1), 79-114. https://doi.org/10.1128/CMR.00015-06

Di Cesare, A., Eckert, E. M., D'Urso, S., Bertoni, R., Gillan, D. C., Wattiez, R., Corno, G., 2016. Co-occurrence of integrase 1, antibiotic and heavy metal resistance genes in municipal $\begin{array}{lllll}\text { wastewater treatment } & \text { plants. Water }\end{array}$ https://doi.org/10.1016/j.watres.2016.02.049

EPA (United States Environmental Protection Agency), 2018. Septic systems overview. Retrieved from: https://www.epa.gov/septic/septic-systems-overview [January 8, 2019].

Freeman, C. N., Scriver, L., Neudorf, K. D., Truelstrup Hansen, L., Jamieson, R. C., Yost, C. K., 2018. Antimicrobial resistance gene surveillance in the receiving waters of an upgraded wastewater treatment plant. FACETS 3(1), 128-138. https://doi.org/10.1139/facets-2017$\underline{0085}$

Gao, P., Munir, M., Xagoraraki, I., 2012. Correlation of tetracycline and sulfonamide antibiotics with corresponding resistance genes and resistant bacteria in a conventional municipal wastewater treatment plant. Science of the Total Environment 421-422 173-183. https://doi.org/10.1016/j.scitotenv.2012.01.061 
530 Gillings, M. R., Gaze, W. H., Pruden, A., Smalla, K., Tiedje, J. M., Zhu, Y. G., 2015. Using the 531 class 1 integron-integrase gene as a proxy for anthropogenic pollution. The ISME $532 \quad$ Journal 9(6), 1269.

533 Government of Canada, 2016. Canadian antimicrobial resistance surveillance system - report

534 2016. Public Health Agency of Canada. Ottawa, Ontario. Retrieved from:

535 https://www.canada.ca/en/public-health/services/publications/drugs-health-

536 products/canadian-antimicrobial-resistance-surveillance-system-report-2016.html\#a4-4-1

$537 \quad$ [January 3, 2019].

538 Government of Canada, 2018. Debert, Nova Scotia. Climate ID 8201390. Past weather and

539 climate. Historical data. Retrieved from:

540 http://climate.weather.gc.ca/climate_data/daily_data_e.html?hlyRange=2003-12-

$541 \quad$ 11\%7C2019-01-02\&dlyRange=2003-12-11\%7C2019-01-02\&mlyRange=2004-01-

$542 \quad \underline{01 \% 7 C 2007-07-}$

543 01\&StationID=42243\&Prov=NS\&urlExtension=_e.html\&searchType=stnProx\&optLimit=y

544 earRange\&StartYear=2017\&EndYear=2019\&selRowPerPage=25\&Line=0\&txtRadius=25\&

545 optProxType $=$ custom \&selCity $=\&$ selPark $=\&$ txtCentralLatDeg $=45 \&$ txtCentralLatMin $=21 \& t$

546 xtCentralLatSec=02\&txtCentralLongDeg=63\&txtCentralLongMin=18\&txtCentralLongSec

$547 \quad=11 \&$ timeframe=2\&Day=2\&Year=2018\&Month=7\# [accessed on January 3, 2018].

548 Kolář, M., Urbánek, K., Látal, T., 2001. Antibiotic selective pressure and development of 549 bacterial resistance. International Journal of Antimicrobial Agents 17(5), 357-363. $550 \quad$ https://doi.org/10.1016/S0924-8579(01)00317-X 
551 Levin, T. P., Suh, B., Axelrod, P., Truant, A. L., Fekete, T., 2005. Potential clindamycin 552 resistance in clindamycin-susceptible, erythromycin-resistant Staphylococcus aureus: report 553 of a clinical failure. Antimicrobial Agents and Chemotherapy 49(3), 1222-1224.

554 Mao, D., Yu, S., Rysz, M., Luo, Y., Yang, F., Li, F., Hou, J., Mu, Q., Alvarez, P. J. J., 2015. 555 Prevalence and proliferation of antibiotic resistance genes in two municipal wastewater treatment plants. Water Research 85, 458-466. https://doi.org/10.1016/j.watres.2015.09.010

McConnell, M. M., Hansen, L. T., Neudorf, K. D., Hayward, J. L., Jamieson, R. C., Yost, C. K., Tong, A., 2018a. Sources of antibiotic resistance genes in a rural river system. Journal of Environmental Quality 47(5), 997 -1005. https://doi.org/10.2134/jeq2017.12.0477

560

McConnell, M. M., Hansen, L. T., Jamieson, R. C., Neudorf, K. D., Yost, C. K., Tong, A., 2018b. Removal of antibiotic resistance genes in two tertiary level municipal wastewater treatment plants. Science of the Total Environment 643, 292-300. https://doi.org/10.1016/j.scitotenv.2018.06.212

Munir, M., Wong, K., Xagoraraki, I., 2011. Release of antibiotic resistant bacteria and genes in the effluent and biosolids of five wastewater utilities in Michigan. Water Research 45(2), 681-693. https://doi.org/10.1016/j.watres.2010.08.033

Neudorf, K. D., Huang, Y. N., Ragush, C. M., Yost, C. K., Jamieson, R. C., Hansen, L. T., 2017. Antibiotic resistance genes in municipal wastewater treatment systems and receiving waters in Arctic Canada. Science of the Total Environment 598, 1085-1094. https://doi.org/10.1016/j.scitotenv.2017.04.151

Nõlvak, H., Truu, M., Tiirik, K., Oopkaup, K., Sildvee, T., Kaasik, A., Mander, U., Truu, J., 2013. Dynamics of antibiotic resistance genes and their relationships with system treatment 
efficiency in a horizontal subsurface flow constructed wetland. Science of the Total Environment 461, 636-644. https://doi.org/10.1016/j.scitotenv.2013.05.052

575 Nova Scotia Environment, 2013. On-site sewage disposal systems: technical guidelines. Disposal field design. Retrieved from: https://novascotia.ca/nse/wastewater/sewagedisposalguide.asp

Pietramellara, G., Ascher, J., Borgogni, F., Ceccherini, M. T., Guerri, G., Nannipieri, P., 2009. [accessed on January 3, 2019].

Poté, J., Ceccherini, M. T., Rosselli, W., Wildi, W., Simonet, P., Vogel, T. M., 2003. Fate and transport of antibiotic resistance genes in saturated soil columns. European Journal of Soil Biology 39(2), 65-71. https://doi.org/10.1016/S1164-5563(03)00003-7

Rizzo, L., Manaia, C., Merlin, C., Schwartz, T., Dagot, C., Ploy, M. C., Michael., I., Fatta-

Schaider, L. A., Rodgers, K. M., Rudel, R. A., 2017. Review of organic wastewater compound concentrations and removal in onsite wastewater treatment systems. Environmental Science

Seurinck, S., Defoirdt, T., Verstraete, W., Siciliano, S. D., 2005. Detection and quantification of 592 the human assessment of human faecal pollution in freshwater. Environmental Microbiology 7(2), 249259. https://doi.org/10.1111/j.1462-2920.2004.00702.x 
595 Sinclair, A., Jamieson, R., Gordon, R. J., Madani, A., Hart, W., 2013. Modeling phosphorus 596 treatment capacities of on-site wastewater lateral flow sand filters. Journal of Environmental 597 Engineering 140(2), 04013002. https://doi.org/10.1061/(ASCE)EE.1943-7870.0000796

598 Statistics Canada, 2015. Households’ use of water and wastewater services. EnviroStats. 16-002599 X. Articles. Retrieved from: https://www150.statcan.gc.ca/n1/pub/16-002$600 \quad \underline{x} \quad \underline{2008004 / a r t i c l e / 10752-e n g . h t m ~}[J a n u a r y ~ 8,2019]$.

601 WHO (World Health Organization), 2014. Antimicrobial resistance global report on 602 surveillance. Geneva, Switzerland. Pp. $256 . \quad$ Retrieved from: 603 http://apps.who.int/iris/bitstream/handle/10665/112642/9789241564748_eng.pdf;jsessionid $604 \quad=1 D 77 E 383104019 B E B 9 C 7998991639 D 13 ?$ sequence=1 [September 25, 2018].

605 Wilhelm, S. R., Schiff, S. L., Cherry, J. A., 1994. Biogeochemical evolution of domestic waste 606 water in septic systems: 1. Conceptual model. Groundwater 32(6), 905-916. $607 \quad$ https://doi.org/10.1111/j.1745-6584.1994.tb00930.x

608 Wilson, J., Boutilier, L., Jamieson, R., Havard, P., Lake, C., 2011. Effects of hydraulic loading 609 rate and filter length on the performance of lateral flow sand filters for on-site wastewater $610 \quad$ treatment. Journal of $\quad$ Hydrologic $\quad$ Engineering 16(8), $\quad$ 639-649. $611 \quad$ https://doi.org/10.1061/(ASCE)HE.1943-5584.0000359

612 WWAP (United Nations World Water Assessment Programme), 2017. The United Nations 613 World Water Development Report 2017. Wastewater: The Untapped Resource. Paris, 614 UNESCO. Retrieved from: https://unesdoc.unesco.org/ark:/48223/pf0000247153 [February 615 11, 2019]. 
616 Zhang, Y., Li, A., Dai, T., Li, F. Xie, H., Chen, L., Wen, D., 2018. Cell-free DNA: A neglected

617 source for antibiotic resistance genes spreading from WWTPs. Environmental Science \&

618 Technology 52, 248-257. https://doi.org/10.1021/acs.est.7b04283 